\title{
MiR-140 in cancer and beyond: a brief update
}

\author{
Yue Zhang ${ }^{1,2}$ \\ 1. Research Center, University of Montreal hospital center (CHUM), Notre Dame Hospital, Montreal, Canada. \\ 2. Department of Radiation Oncology, Beth Israel Deaconess Medical Center, Harvard medical School, Boston, USA. \\ * This work has been invited in 2 and the present address of corresponding author is 1 .
}

Correspondence: Yue Zhang. Address: 1560 Sherbrooke Street East, Pavillon DeSève, Room Y2625, Montreal, Quebec, H2L 4M1, Canada. Email: zy1001@yahoo.com

Received: October 18, 2012

DOI : $10.5430 /$ jst.v3n1p38
Accepted: December 2, 2012 Online Published: December 20, 2012

URL: http://dx.doi.org/10.5430/jst.v3n1p38

\section{Abstract}

Cancer chemotherapy causes many side-effects, including joint pain. We speculate that a better understanding of the common biology of cancer and osteoarthritis could help us to find out ways to cure the cancer and to alleviate pain if their shared mechanisms are responsible for joint pain and/or related side-effects. In this mini-vision and reflection, we focus on the networks of miR-140 that are involved in both cancer and osteoarthritis during development and carcinogenesis. Frontiers including autophagy, potential stem-cell therapy and early nanotechnological diagnosis of those diseases will be briefly discussed.

\section{Key words}

MiR-140, Cancer, Osteoarthritis, Stem cell, Autophagy

\section{Introduction}

MicroRNA (miRNA), first discovered in nematode (Caenorhabditis elegans) two decades ago, play a significant role in cancer $^{[1,2]}$. They are single-stranded, non-coding RNAs that regulate mRNA expression at the post-transcriptional level with base-pairing repression of gene expression in 3 untranslated regions (UTR) of targeted genes and play important roles in many fundamental biological processes, such as differentiation, proliferation and migration. MiR-140 was first reported around 10 years ago ${ }^{[3]}$. Later, it was also associated with mesenchymal stem cells (MSCs) and chondrogenesis ${ }^{[4-6]}$. The unique miR140 is evolutionarily conserved among vertebrates and is abundantly and almost exclusively expressed in chondrocytes. The differential expression of miR-140 was also validated in hematopoietic stem cells during activation ${ }^{[7]}$. Carcinogenesis and chondrogenesis are likely to be related to the differentiation of stem-like or progenitor cells ${ }^{[8-10]}$. The emerging evidence has shown that there is common biology between cancer and osteoarthritis (OA), two complex ageing-related diseases, which thus far the overall effects and quality of life of patients have not improved significantly over the past decade despite recent advancements in multidisciplinary treatments, but have many details remaining to be determined. Among many factors that may cause joint pain, we speculate that these shared mechanisms are possibly responsible for joint pain and/or related side-effects, along with cancer chemotherapy and OA. Since joint pain is the primary symptom associated with osteoarthritis, thus a better understanding of these points will be helpful to develop a strategy to reduce some side-effects. Normally, the function of cartilage relies on collagens, proteoglycans and chondrocytes. Chondrocytes usually break down and get rid of old proteglycan and collagen forming new ones to take 
their place. When the cartilage that cushions bone ends no longer does its jobs, the joint pain begins. OA is the result of the breakdown of cartilage inside the joint. In this mini-vision and reflections, we briefly summarize some important recent findings of the involvement of miR-140 in both cancer and OA during development and carcinogenesis. Their common biology, potential stem cell-related therapy and a novel means of diagnosis for cancer and OA will also be briefly discussed.

\section{MiR-140 and cancer}

UL16-binding protein (ULBP)1-specific miR-140 is expressed in HeLa and Jurkat cells, and the involvement of this miRNA is via a $3^{\prime}$ UTR-mediated mechanism of regulation of ULBP1 at the post-transcriptional level ${ }^{[11]}$. The stress-inducible ULBP1 cell surface ligand for the activating immunoreceptor NKG2D allows recognition and lysis of tumor cells by natural killer and T-cells. Nicotine increases expression of miR-140, coordinated with the nicotine-augmented expression of its host gene, WW domain-containing protein 2 (WWP2). Furthermore, miR-140 targets the $3^{\prime}$-UTR of the dynamin 1 gene (Dnm1) by direct base-pairing ${ }^{[12]}$. In HeLa cells, inhibition of miR-140 downregulates cell growth, according to another report ${ }^{[13]}$.

Figure 1. The network of miR-140 in cancer. In red: direct inhibition or repression; In green: promotion or activation.

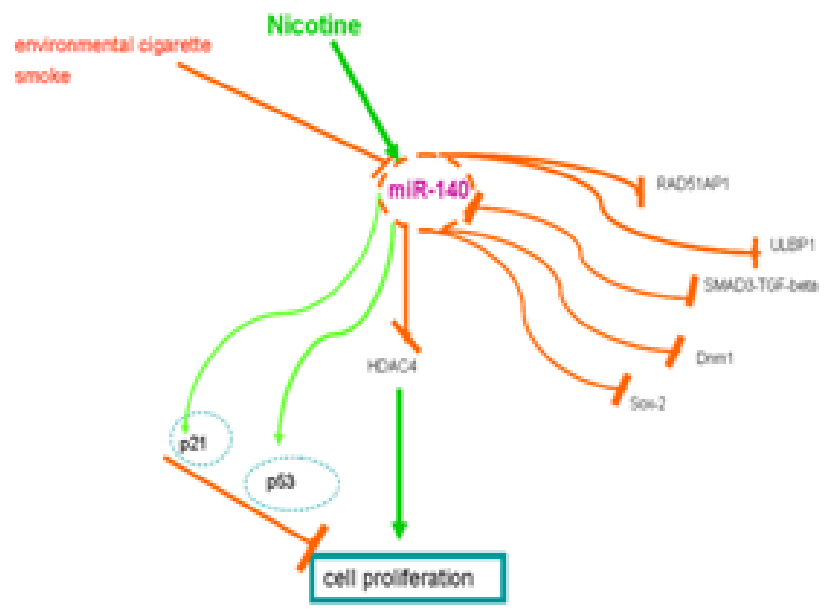

MiR-140 has been shown to be among the driving miRNAs in colorectal tumours ${ }^{[14]}$. Moreover, in comparison with the normal ovary, miRNAs are aberrantly expressed in ovarian cancer. The most significantly overexpressed miRNAs include miR-200a, miR-200c and miR-200b, whereas miR-140 is among the most downmodulated miRNAs ${ }^{[15]}$. Additionally, the expression level of RAD51AP1 has been found to have a negative correlation with the expression of hsa-miR-140, which was significantly downregulated in the tumour samples, suggesting a direct causal dysregulation of RAD51AP1 by hsa-miR-140 in the ovary ${ }^{[16]}$. Interestingly, a 5-miRNA classifier including miR-140 could distinguish squamous cell carcinoma from normal lung tissues with a very high accuracy, further direction need explore if such classifier could be possibly predictive for early diagnosis ${ }^{[17]}$. In sporadic clinically non-functioning pituitary adenomas, five miRNAs predicted to target Smad3, including miR-140, were overexpressed ${ }^{[18]}$. In multiple myeloma, the occurrence of several allelic imbalances or a loss of heterozygosity were found to be significantly associated with the altered expression of miRNAs located in the regions involved, such as miR-140 at 16q22 ${ }^{[19]}$. During glioma progression, a group of 12 miRNAs, including miR-140, have increased expression ${ }^{[20]}$. Tumor cells ectopically transfected with miR-140 became more resistant to methotrexate and 5-fluorouracil. Ectopic expression of miR-140 inhibited cell proliferation in both osteosarcoma U-2 OS and colon cancer HCT 116 cell lines. MiR-140 induced p53 and p21 expression accompanied with G(1) and G(2) phase arrest. Histone deacetylase 4 (HDAC4) was confirmed as one target of miR-140. The expression of endogenous miR-140 was significantly elevated in CD133(+hi) CD44/MMP-9(+hi) colon cancer stem-like cells that 
exhibit a slow rate of proliferation and chemoresistance. MiR-140 contributes to chemoresistance via reduced cell proliferation through $\mathrm{G}(1)$ and $\mathrm{G}(2)$ phase arrest mediated partially through the suppression of HDAC4 ${ }^{[21]}$. In progressive stages of endothelial cell transformation cumulating in Kaposi's sarcoma, miR-140 and Kaposi's sarcoma-associated herpes virus miRNAs increased linearly with the degree of transformation ${ }^{[22]}$. The most remarkably downregulated microRNAs belong to several families, including miR-140, along with the lungs of rats exposed to environmental cigarette smoke. There was a strong parallelism between the dysregulation of rodent miRNAs and their human homologues, which are often transcribed from genes localized in fragile sites deleted in lung cancer ${ }^{[23]}$. Comparison of the global expression profiles of miRNAs in primary breast cancer and normal adjacent tumor tissues reveals that seven miRNAs, including miR-140, are down-regulated, more than twofold ${ }^{[24]}$. From one latest breast cancer study, we can understand that estrogen receptor alpha signaling regulates breast tumor-initiating cells by down-regulating miR-140 which targets the transcription factor , i.e. the stem cell self-renewal regulator SRY (sex determining region Y)-box 2 (SOX2) ${ }^{[25]}$. The network of miR-140 in cancer is summarized in Figure 1, and the cancer types linked with miR-140 are shown in Table 1.

Table 1. MiR-140's involvement in cancer

\begin{tabular}{ll}
\hline Type & References \\
\hline Colorectal tumor & 13 \\
Ovarian cancer & 14,15 \\
Squamous cell carcinoma & 16 \\
Non-functioning pituitary adenomas & 17 \\
Glioma & 19 \\
Kaposi's sarcoma & 21 \\
Lung cancer & 22 \\
Breast cancer & $23-24$ \\
\hline
\end{tabular}

\section{MiR-140 and cartilage}

The expression of several miRNAs is regulated during chondrogenesis. These miRNAs are coexpressed with miR-140, which is known to be involved in cartilage homeostasis and OA. When human OA cartilage was compared with cartilage obtained from patients with femoral neck fractures, the expression of both miR-140-5p and miR-455-3p was increased in OA cartilage ${ }^{[26]}$. Increased miR-145 levels cause greatly reduced expression of the critical cartilage extracellular matrix genes [type II collagen (COL2A1) and cartilage-specific proteoglycan core protein (AGGRECAN)], and of tissue-specific miRNAs (including miR-140) and increased levels of the hypertrophic markers RUNX2 and matrix metalloproteinase13(MMP13), characteristic of changes occurring in $\mathrm{OA}^{[27]}$.

One independent study shows that miR-140 had the largest difference in expression between chondrocytes and MSCs. During chondrogenesis, miR-140 expression in MSC cultures increased in parallel with the expression of SOX9 and COL2A1. Normal human articular cartilage expressed miR-140, and this expression was significantly reduced in OA tissue. In vitro treatment of chondrocytes with IL-1beta suppressed miR-140 expression. Transfection of chondrocytes with ds-miR-140 down-regulated IL-1beta-induced ADAMTS5 expression and rescued the IL-1beta-dependent repression of AGGRECAN gene expression ${ }^{[4]}$.

Downstream target identification reveals significance of miR-140 underlying mechanism in cartilage. Expression of mRNAs was profiled in both the cartilage-specific miR-140 overexpressed and silenced in cells it is normally expressed in separate experiments and the intersection of mRNAs repressed by miR-140 overexpression and derepressed by silencing of miR-140 was identified. The intersection contained only 49 genes, which showed a very strong enrichment for the miR-140 seed sequence. One of the potential direct target mRNAs, the CXC group of chemokine ligand 12(Cxcl12, also known as Stromal-derived factor 1; SDF-1) was experimentally validated ${ }^{[28]}$. MiR-140 is specifically expressed in the 
cartilage tissues of mouse embryos during both long and flat bone development. HDAC4 was validated experimentally as

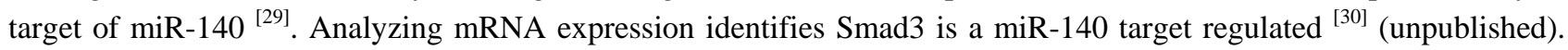
Further, there was a significant reduction in miR-140 expression in OA compared to the normal chondrocytes. Transfection with pre-miR-140 significantly decreased IGFBP-5 expression, while transfection with anti-miR-140 significantly increased it. Treatment with anti-miR-140 did not significantly increase the expression of both MMP-13 and IGFBP-5. MMP-13 and IGFBP-5 protein production had the same patterns as their expression profile. Therefore IGFBP-5 is a direct target of miR-140 ${ }^{[31]}$.

Figure 2. The network of miR-140 in cartilage. In red: direct inhibition or repression; In green: promotion or activation; In blue: miR-145 specific promotion or activation.

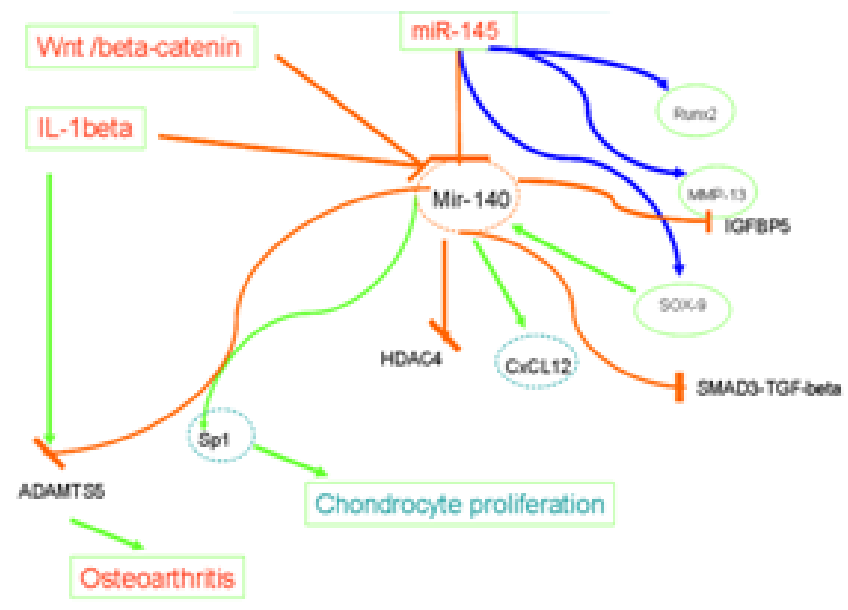

Other studies reveal the miR-140 cross-talks with other cell signalling pathways. In developing zebrafish (Danio rerio), sox9a mutant (sox9a-/-) and sox9b mutant (sox9b-/-) zebrafish and SOX9 small interfering RNA in human chondrocytes, T/C-28 cells, miR-140 is regulated by the cartilage master transcription regulator Sox $9^{[32]}$. The proximal upstream region of pri-miR-140 has chondrogenic promoter activity in vivo. There is an L-Sox5/Sox6/Sox9 (Sox trio) response element in the promoter region. Furthermore, the DNA binding and/or transactivation ability of Sox9 as a homodimer is boosted by L-Sox5 and Sox ${ }^{[33]}$. Intergenic and intronic miR-140 in whole mounts and histological sections showed that pri-miRNA ISH provides an attractive and cost-effective tool to study miRNA expression. The chondrocyte miRNA miR-140 lies downstream of Sox9 in the development of the craniofacial skeleton ${ }^{[34]}$. MiR-140 is uniquely expressed in the chondrocytes and suppressed by Wnt/beta-catenin signalling. The miR-140 primary transcript is an intron-retained RNA co-expressed by the Wwp2-C isoform, which was directly induced by Sox9 through binding to intron 10 of the Wwp2 gene. MiR-140 in limb bud micromass cultures is required for maintenance of the chondrocyte proliferation. Sp1, the activator of the cell cycle regulator p15 (INK4b), is a target of miR-140 in maintaining chondrocyte proliferation ${ }^{\text {[35] }}$. MiR-140 is involved in the pathogenesis of OA by regulating a disintegrin and metalloproteinase with thrombospondin motifs (ADAMTS5) ${ }^{[36]}$. Mice with a miR-140 deficiency are dwarfs as a consequence of impaired chondrocyte proliferation ${ }^{[6]}$. The network of miR-140 in cartilage is summarized in (Figure 2).

\section{MiR-140 and development}

MiRNA are essential for the aforementioned chondrogenesis and for many other processes of development. For example, down-regulation of miR-140 is associated with body growth and particularly useful for Nile tilapia (Oreochromis niloticus) breeding programs ${ }^{[37]}$. Ethanol and nicotine co-regulated miR-140, as ethanol suppressed the expression of miR-140-3p, while nicotine at the concentrations attained by cigarette smokers induced a dose-related increase it in fetal neural stem cells ${ }^{[38]}$. MiR-140 has been identified as a functional regulator of dedifferentiation/proliferation and remyelination in mouse Schwann cells, which is critical for nerve regeneration. MiR-140 targeted the transcription factor 
Egr2, a master regulator of myelination ${ }^{[39]}$. It has been proposed that endogenous old astrocyte specifically induced substance (OASIS) protein is expressed at low levels in pancreatic beta-cell lines and rodent islets, possibly due to the abundant levels of miR-140 present in these cells ${ }^{[40]}$. One analysis of miRNA expression in whole blood of 12 patients with CAD (coronary artery disease) and 12 healthy control subjects revealed a number of differentially expressed miRNAs, including hsa-miR-140. By using whole blood as a 'surrogate tissue' in patients with CAD, differentially expressed miRNAs such as miR-140 and modulated pathways warrant further investigation in the setting of cardiovascular function through such a novel non-invasive strategy ${ }^{[41]}$. MiRNA-140, miRNA-200c and others showed distinct temporal and spatial expression patterns in the postnatal mouse inner ear ${ }^{[42]}$. MiR-140 was also found to regulate palatal development ${ }^{[43]}$. MiR-140 was found to regulate important genes related to the beta-catenin pathway: WNT5A, ZIC1 and TGFB1 ${ }^{[44]}$. MiR-140 suppressed the TGF-beta pathway through repression of Smad3, and TGF-beta suppressed the accumulation of miR-140, forming a double negative feedback loop ${ }^{[30]}$. When exposed to IL-1beta, TNF-alpha and IFN-gamma, airway smooth muscle cells decrease expression of miR-140 ${ }^{[45]}$. Examination of the miRNA expression profiles showed time-dependent increases in miR-140 ${ }^{[46]}$. Interestingly, miR-140 is also critical for metamorphosis of the Japanese flounder (Paralichthys olivaceus) ${ }^{[47]}$. Finally, miR-140 regulates endochondral bone development and targets Dnpep to modulate bone morphogenetic protein signaling ${ }^{[48]}$.

The network of miR-140 in development is summarized in Figure 3.

Figure 3. The network of miR-140 in development. In red: direct inhibition or repression; In green: promotion or activation; In blue: miR-145 specific promotion or activation.

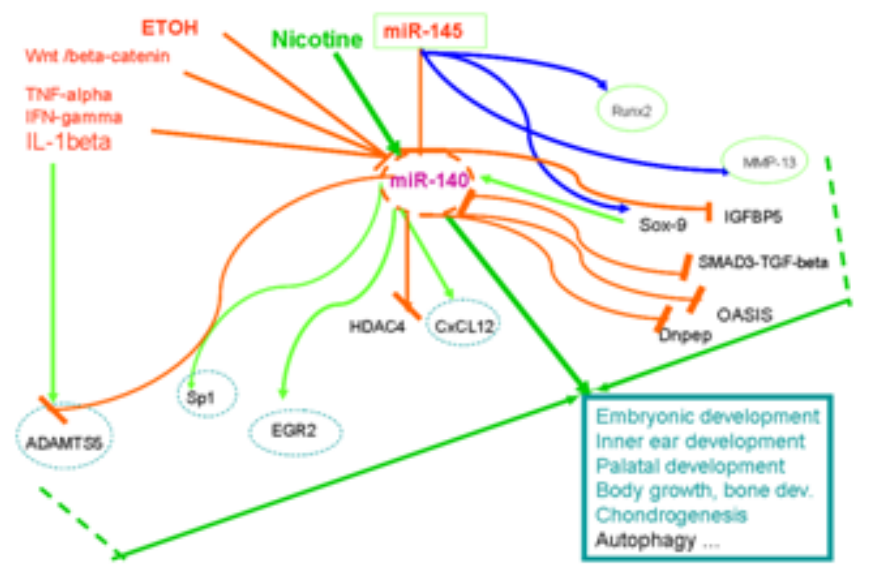

\section{Discussion}

MiR-140 networks are partially overlapped between cancer and OA, such as the sharing HDAC4 downstream activities and SMAD3-TGF-beta pathway. We can speculate that the critical stemness genes-related pathway such as SOX2/miR-140 in breast cancer might have important roles in OA too. Further, some developmental roles of miR-140 raise the possibility to find out more shared underlying mechanisms for cancer and OA. In addition, we believe that a better picture of miR-140 in normal physiology and development at a system level can benefit our future OA and cancer prevention as well as therapeutic implications. Clearly, we understand that early steps to avoid disease are always the best cure.

But beyond the abovementioned, many remarkable common features between cancer and OA emerge, in the near future, we need explore how miR-140 gets involved in such features: the dysregulation of extracellular matrix and matrix-resolving properties (CD44/MMP9 and MMP13) ${ }^{[21]}$ and hypoxia (i.e. low-oxygen conditions) inducible properties (HIF1, HIF2) ${ }^{[32]}$, coupled with mesenchymal cells (e.g. the CxCL12-CXCR4 axis) ${ }^{[49]}$; sensitivity to antirheumatics; constitutive activation of NFkappaB, the Wnt/beta-catenin cell signalling pathway, the shared cytokine and chemokine 
signalling pathways, and the COX-2/PGE2 pathway ${ }^{[50]}$; finally some overlapping extraterritorial osteoclast traits of primary cancer cells ${ }^{[51]}$.

As for joint pain, it is the primary symptom associated with OA and also a common side effect of hormone therapy for breast cancer treatment because it halts estrogen production in post-menopausal women. These treatments can slow the production of estrogen, which means that there is less of it to fuel breast cancer cell growth. Tamoxifen treatment may produce OA-like aches and stiffness. While the mechanism causing joint pain is still rather open, we now start to know that estrogen receptor alpha signaling regulates breast tumor-initiating cells by down-regulating miR-140, which targets the transcription factor, i.e. the stem cell self-renewal regulator SOX-2 ${ }^{[25]}$. Consequently, we could speculate such chemotherapy might disturb those shared underlying mechanisms to some extent and hence likely cause joint pain in OA as well ${ }^{[52]}$. However, rare gene or miRNAs is abundantly and almost exclusively expressed in chondrocytes as miRNA-14. In one hand, because studies of miR-140 have experienced for less than 10 years, currently it remains tempting to see how miR-140 alone or together with other factors may affect joint pain, thus further investigation needs. In another hand, complex diseases such as cancer and OA, like an avalanche, are likely due to a failure of self-organisation system within epigenetic landscape ${ }^{[53]}$. Understanding the roles of such chondrocytes -specific exclusively expressed miR-140 in joint pain could provide some insights on system failure of OA and cancer. Among many other miRNAs, miR-200, miR-145, miR-140 are known to involve in both cancer and $\mathrm{OA}^{[10,27,54-56]}$, so there would be miRNAs -network rather than miR-140 alone to orchestrate such complex diseases ${ }^{[2]}$. Then some self-organisation map tools such as gene expression dynamics inspectors (GEDI) ${ }^{[57,58]}$ or the like ${ }^{[59]}$ can be helpful for early prediction and diagnosis of complex diseases, such as cancer and OA.

Furthermore, we hypothesize that they both are likely to share some important features in autophagy-related pathways as well ${ }^{[6061]}$ (Zhang Y et al, in preparation). For instance, some autophagy-related genes, such as, at least ATG-5, EGR-1, and MAP1LC3A/LC3A/ATG8 predicted to be a direct target of miR-140, are involved in autophagy and are frequently inactivated in human cancers ${ }^{[62]}$ and preliminary data shows that they are dys-regulated in OA (Zhang Y et al, in preparation). Interestingly, artificial hypoxia-like states, such as exercise, can induce autophagy ${ }^{\text {[63] }}$. The hypoxic state has a significant effects on understanding ${ }^{[64]}$, prevention and stem cell/progenitor cell-related therapy for both cancer and $\mathrm{OA}^{[65,66] .}$ Elucidating the interplay between autophagy, cancer and OA will provide unique opportunities to identify new therapeutic targets ${ }^{[67]}$ and to develop novel treatment strategies and reduction of the side-effects of those affected by cancer chemotherapy via targeting both cellular homeostasis mechanisms, such as autophagy, and miRNAs epigenetics. Hopefully, the inducers for autophagy such as rapamycin can be applied in "cocktail” therapies in combination with cancer chemotherapy and/or OA treatments in the future.

Interestingly, latest research shows that stem cell therapy and nanotech diagnosis are promising frontiers for both diseases. Some labs have developed different protocols for cancer cell reprogramming and therapy ${ }^{[68,69]}$. In OA settings, the adult MSCs are thought to repair injured tissue. The repair tissue from human articular cartilage during the late stages of OA harbours a unique progenitor cell population, termed chondrogenic progenitor cells, which exhibit stem cell characteristics combined with a high degree of chondrogenic potential. They offer new insights into novel therapeutic approaches for the late stages of $\mathrm{OA}^{[70,71]}$. As aforementioned, miR-140 targets the stemness gene SOX2 in breast cancer, it might give us warrant to explore its contribution to adult stem cells in tissue repair in OA too. Moreover, a kartogenin promotes stem cells to make cartilage. Treatment with kartogenin allowed many mice with surgery to correct arthritis-like cartilage damage in a knee to re-use the joint without pain ${ }^{[72]}$.

For early diagnosis, nanotechnology made for Mars, known as “ARTIDIS”, holds promise for detecting breast cancer and $\mathrm{OA}$ in that it builds on the exquisite nanomechanical sensitivity of the atomic force microscope to detect and differentiate between the various stages of disease in soft human tissues - in a matter of minutes, while conventional breast cancer diagnostics often involve much longer times. Through it, one can also investigate degenerative arthritis. In comparison to conventional methods, the atomic force microscope has the potential to determine the onset of disease. The possibility of 
diagnosis with ARTIDIS in the early stages is encouraging for better treatment options, with potentially higher chances of cure. Lastly, it is not unexpected that the nano-material combined with short non-coding RNAs such as miRNAs, including miR-140, could become feasible as an in vivo delivery therapeutic toolkit. Blocking endogenous miR-140 by locked nucleic acid-modified anti-miR partially sensitized the resistant colon cancer stem-like cells to 5-fluorouracil treatment. On the other hand, it is not unexpected that fine adjustment of miR-140 expression could alleviate joint pain and OA.

\section{References}

[1] Ruvkun G. Clarifications on miRNA and cancer. Science. 2006; 311: 36-7. PMid:16400132

http://dx.doi.org/10.1126/science.311.5757.36d

[2] Guo Y, Feng Y, Trivedi NS, Huang S. Medusa structure of the gene regulatory network: dominance of transcription factors in cancer subtype classification. Experimental biology and medicine. 2011; 236: 628-36. PMid:21540249 http://dx.doi.org/10.1258/ebm.2011.010324

[3] Wienholds E, Kloosterman WP, Miska E, Alvarez-Saavedra E, Berezikov E, de Bruijn E, et al. MicroRNA expression in zebrafish embryonic development. Science. 2005; 309: 310-1. PMid:15919954 http://dx.doi.org/10.1126/science.1114519

[4] Miyaki S, Nakasa T, Otsuki S, Grogan SP, Higashiyama R, Inoue A, et al. MicroRNA-140 is expressed in differentiated human articular chondrocytes and modulates interleukin-1 responses. Arthritis and rheumatism. 2009; 60: 2723-30. PMid:19714579 http://dx.doi.org/10.1002/art.24745

[5] Liu SP, Fu RH, Yu HH, Li KW, Tsai CH, Shyu WC, et al. MicroRNAs regulation modulated self-renewal and lineage differentiation of stem cells. Cell transplantation. 2009; 18: 1039-45. PMid:19523330 http://dx.doi.org/10.3727/096368909X471224

[6] Miyaki S, Sato T, Inoue A, Otsuki S, Ito Y, Yokoyama S, et al. MicroRNA-140 plays dual roles in both cartilage development and homeostasis. Genes \& development. 2010; 24: 1173-85. PMid:20466812 http://dx.doi.org/10.1101/gad.1915510

[7] Guo CJ, Pan Q, Li DG, Sun H, Liu BW. MiR-15b and miR-16 are implicated in activation of the rat hepatic stellate cell: An essential role for apoptosis. Journal of hepatology. 2009; 50: 766-78. PMid:19232449 http://dx.doi.org/10.1016/j.jhep.2008.11.025

[8] Koelling S, Kruegel J, Irmer M, Path JR, Sadowski B, Miro X, et al. Migratory chondrogenic progenitor cells from repair tissue during the later stages of human osteoarthritis. Cell stem cell. 2009; 4: 324-35. PMid:19341622 http://dx.doi.org/10.1016/j.stem.2009.01.015

[9] Zhang Y, Moriguchi H. Chromatin remodeling system, cancer stem-like attractors, and cellular reprogramming. Cellular and molecular life sciences. 2011; 68: 3557-71. PMid:21909785 http://dx.doi.org/10.1007/s00018-011-0808-1

[10] Yang B, Guo H, Zhang Y, Chen L, Ying D, Dong S. MicroRNA-145 regulates chondrogenic differentiation of mesenchymal stem cells by targeting Sox9. PloS one. 2011; 6: e21679. PMid:21799743 http://dx.doi.org/10.1371/journal.pone.0021679

[11] Himmelreich H, Mathys A, Wodnar-Filipowicz A, Kalberer CP. Post-transcriptional regulation of ULBP1 ligand for the activating immunoreceptor NKG2D involves 3' untranslated region. Human immunology. 2011; 72: 470-8. PMid:21406206 http://dx.doi.org/10.1016/j.humimm.2011.03.005

[12] Huang W, Li MD. Nicotine modulates expression of miR-140*, which targets the 3'-untranslated region of dynamin 1 gene (Dnm1). The international journal of neuropsychopharmacology. 2009; 12: 537-46. PMid:18845019 http://dx.doi.org/10.1017/S1461145708009528

[13] Cheng AM, Byrom MW, Shelton J, Ford LP. Antisense inhibition of human miRNAs and indications for an involvement of miRNA in cell growth and apoptosis. Nucleic acids research. 2005; 33: 1290-7. PMid:15741182 http://dx.doi.org/10.1093/nar/gki200

[14] Piepoli A, Tavano F, Copetti M, Mazza T, Palumbo O, Panza A, et al. Mirna expression profiles identify drivers in colorectal and pancreatic cancers. PloS one. 2012; 7: e33663. PMid:22479426 http://dx.doi.org/10.1371/journal.pone.0033663

[15] Iorio MV, Visone R, Di Leva G, Donati V, Petrocca F, Casalini P, et al. MicroRNA signatures in human ovarian cancer. Cancer research. 2007; 67: 8699-707. PMid:17875710 http://dx.doi.org/10.1158/0008-5472.CAN-07-1936

[16] Miles GD, Seiler M, Rodriguez L, Rajagopal G, Bhanot G. Identifying microRNA/mRNA dysregulations in ovarian cancer. BMC research notes. 2012; 5: 164. PMid:22452920 http://dx.doi.org/10.1186/1756-0500-5-164

[17] Tan X, Qin W, Zhang L, Hang J, Li B, Zhang C, et al. A 5-microRNA signature for lung squamous cell carcinoma diagnosis and hsa-miR-31 for prognosis. Clinical cancer research. 2011; 17: 6802-11. PMid:21890451

http://dx.doi.org/10.1158/1078-0432.CCR-11-0419 
[18] Butz H, Liko I, Czirjak S, Igaz P, Korbonits M, Racz K, et al. MicroRNA profile indicates downregulation of the TGFbeta pathway in sporadic non-functioning pituitary adenomas. Pituitary. 2011; 14: 112-24. PMid:21063788 http://dx.doi.org/10.1007/s11102-010-0268-x

[19] Lionetti M, Biasiolo M, Agnelli L, Todoerti K, Mosca L, Fabris S, et al. Identification of microRNA expression patterns and definition of a microRNA/mRNA regulatory network in distinct molecular groups of multiple myeloma. Blood. 2009; 114: e20-6. PMid:19846888 http://dx.doi.org/10.1182/blood-2009-08-237495

[20] Malzkorn B, Wolter M, Liesenberg F, Grzendowski M, Stuhler K, Meyer HE, et al. Identification and functional characterization of microRNAs involved in the malignant progression of gliomas. Brain pathology. 2010; 20: 539-50. PMid:19775293 http://dx.doi.org/10.1111/j.1750-3639.2009.00328.x

[21] Song B, Wang Y, Xi Y, Kudo K, Bruheim S, Botchkina GI, et al. Mechanism of chemoresistance mediated by miR-140 in human osteosarcoma and colon cancer cells. Oncogene. 2009; 28: 4065-74. PMid:19734943 http://dx.doi.org/10.1038/onc.2009.274

[22] O'Hara AJ, Chugh P, Wang L, Netto EM, Luz E, Harrington WJ, et al. Pre-micro RNA signatures delineate stages of endothelial cell transformation in Kaposi sarcoma. PLoS pathogens. 2009; 5: e1000389. PMid:19381257 http://dx.doi.org/10.1371/journal.ppat.1000389

[23] Izzotti A, Calin GA, Arrigo P, Steele VE, Croce CM, De Flora S. Downregulation of microRNA expression in the lungs of rats exposed to cigarette smoke. FASEB journal. 2009; 23: 806-12. PMid:18952709 http://dx.doi.org/10.1096/fj.08-121384

[24] Yan LX, Huang XF, Shao Q, Huang MY, Deng L, Wu QL, et al. MicroRNA miR-21 overexpression in human breast cancer is associated with advanced clinical stage, lymph node metastasis and patient poor prognosis. Rna. 2008; 14: $2348-60$. PMid:18812439 http://dx.doi.org/10.1261/rna.1034808

[25] Zhang Y, Eades G, Yao Y, Li Q, Zhou Q. Estrogen Receptor alpha Signaling Regulates Breast Tumor-initiating Cells by Downregulating miR-140 which Targets the Transcription Factor SOX2. The Journal of biological chemistry. 2012.

[26] Swingler TE, Wheeler G, Carmont V, Elliott HR, Barter MJ, Abu-Elmagd M, et al. The expression and function of microRNAs in chondrogenesis and osteoarthritis. Arthritis and rheumatism. 2012; 64: 1909-19. PMid:22143896 http://dx.doi.org/10.1002/art.34314

[27] Martinez-Sanchez A, Dudek KA, Murphy CL. Regulation of human chondrocyte function through direct inhibition of cartilage master regulator SOX9 by microRNA-145 (miRNA-145). The Journal of biological chemistry. 2012; 287: 916-24. PMid:22102413 http://dx.doi.org/10.1074/jbc.M111.302430

[28] Nicolas FE, Pais H, Schwach F, Lindow M, Kauppinen S, Moulton V, et al. Experimental identification of microRNA-140 targets by silencing and overexpressing miR-140. Rna. 2008; 14: 2513-20. PMid:18945805 http://dx.doi.org/10.1261/rna.1221108

[29] Tuddenham L, Wheeler G, Ntounia-Fousara S, Waters J, Hajihosseini MK, Clark I, et al. The cartilage specific microRNA-140 targets histone deacetylase 4 in mouse cells. FEBS letters. 2006; 580: 4214-7. PMid:16828749 http://dx.doi.org/10.1016/j.febslet.2006.06.080

[30] Pais H, Nicolas FE, Soond SM, Swingler TE, Clark IM, Chantry A, et al. Analyzing mRNA expression identifies Smad3 as a microRNA-140 target regulated only at protein level. Rna. 2010; 16: 489-94. PMid:20071455 http://dx.doi.org/10.1261/rna.1701210

[31] Tardif G, Hum D, Pelletier JP, Duval N, Martel-Pelletier J. Regulation of the IGFBP-5 and MMP-13 genes by the microRNAs miR-140 and miR-27a in human osteoarthritic chondrocytes. BMC musculoskeletal disorders. 2009; 10: 148. PMid:19948051 http://dx.doi.org/10.1186/1471-2474-10-148

[32] Nakamura Y, He X, Kato H, Wakitani S, Kobayashi T, Watanabe S, et al. Sox9 is upstream of microRNA-140 in cartilage. Applied biochemistry and biotechnology. 2012; 166: 64-71. PMid:22052544 http://dx.doi.org/10.1007/s12010-011-9404-y

[33] Yamashita S, Miyaki S, Kato Y, Yokoyama S, Sato T, Barrionuevo F, et al. L-Sox5 and Sox6 proteins enhance chondrogenic miR-140 microRNA expression by strengthening dimeric Sox9 activity. The Journal of biological chemistry. 2012; 287: $22206-15$. PMid:22547066 http://dx.doi.org/10.1074/jbc.M112.343194

[34] He X, Yan YL, DeLaurier A, Postlethwait JH. Observation of miRNA gene expression in zebrafish embryos by in situ hybridization to microRNA primary transcripts. Zebrafish. 2011; 8: 1-8. PMid:21288128 http://dx.doi.org/10.1089/zeb.2010.0680

[35] Yang J, Qin S, Yi C, Ma G, Zhu H, Zhou W, et al. MiR-140 is co-expressed with Wwp2-C transcript and activated by Sox9 to target Sp1 in maintaining the chondrocyte proliferation. FEBS letters. 2011; 585: 2992-7. PMid:21872590 http://dx.doi.org/10.1016/j.febslet.2011.08.013

[36] Glasson SS, Askew R, Sheppard B, Carito B, Blanchet T, Ma HL, et al. Deletion of active ADAMTS5 prevents cartilage degradation in a murine model of osteoarthritis. Nature. 2005; 434: 644-8. PMid:15800624 http://dx.doi.org/10.1038/nature03369

[37] Huang CW, Li YH, Hu SY, Chi JR, Lin GH, Lin CC, et al. Differential expression patterns of growth-related microRNA in the skeletal muscle of Nile tilapia (Oreochromis niloticus). Journal of animal science. 2012. http://dx.doi.org/10.2527/jas.2012-5142 
[38] Balaraman S, Winzer-Serhan UH, Miranda RC. Opposing Actions of Ethanol and Nicotine on MicroRNAs are Mediated by Nicotinic Acetylcholine Receptors in Fetal Cerebral Cortical-Derived Neural Progenitor Cells. Alcoholism, clinical and experimental research. 2012. PMid:22458409 http://dx.doi.org/10.1111/j.1530-0277.2012.01793.x

[39] Viader A, Chang LW, Fahrner T, Nagarajan R, Milbrandt J. MicroRNAs modulate Schwann cell response to nerve injury by reinforcing transcriptional silencing of dedifferentiation-related genes. The Journal of neuroscience. 2011; 31: $17358-69$. PMid:22131398 http://dx.doi.org/10.1523/JNEUROSCI.3931-11.2011

[40] Vellanki RN, Zhang L, Guney MA, Rocheleau JV, Gannon M, Volchuk A. OASIS/CREB3L1 induces expression of genes involved in extracellular matrix production but not classical endoplasmic reticulum stress response genes in pancreatic beta-cells. Endocrinology. 2010; 151: 4146-57. PMid:20668028 http://dx.doi.org/10.1210/en.2010-0137

[41] Taurino C, Miller WH, McBride MW, McClure JD, Khanin R, Moreno MU, et al. Gene expression profiling in whole blood of patients with coronary artery disease. Clinical science. 2010; 119: 335-43. PMid:20528768 http://dx.doi.org/10.1042/CS20100043

[42] Wang XR, Zhang XM, Zhen J, Zhang PX, Xu G, Jiang H. MicroRNA expression in the embryonic mouse inner ear. Neuroreport. 2010; 21: 611-7. PMid:20467336 http://dx.doi.org/10.1097/WNR.0b013e328338864b

[43] Li L, Meng T, Jia Z, Zhu G, Shi B. Single nucleotide polymorphism associated with nonsyndromic cleft palate influences the processing of miR-140. American journal of medical genetics Part A. 2010; 152A: 856-62. PMid:20358594 http://dx.doi.org/10.1002/ajmg.a.33236

[44] Mosakhani N, Guled M, Lahti L, Borze I, Forsman M, Paakkonen V, et al. Unique microRNA profile in Dupuytren's contracture supports deregulation of beta-catenin pathway. Modern pathology. 2010; 23: 1544-52. PMid:20676061 http://dx.doi.org/10.1038/modpathol.2010.146

[45] Kuhn AR, Schlauch K, Lao R, Halayko AJ, Gerthoffer WT, Singer CA. MicroRNA expression in human airway smooth muscle cells: role of miR-25 in regulation of airway smooth muscle phenotype. American journal of respiratory cell and molecular biology. 2010; 42: 506-13. PMid:19541842 http://dx.doi.org/10.1165/rcmb.2009-0123OC

[46] Moschos SA, Williams AE, Perry MM, Birrell MA, Belvisi MG, Lindsay MA. Expression profiling in vivo demonstrates rapid changes in lung microRNA levels following lipopolysaccharide-induced inflammation but not in the anti-inflammatory action of glucocorticoids. BMC genomics. 2007; 8: 240. PMid:17640343 http://dx.doi.org/10.1186/1471-2164-8-240

[47] Fu Y, Shi Z, Wu M, Zhang J, Jia L, Chen X. Identification and differential expression of microRNAs during metamorphosis of the Japanese flounder (Paralichthys olivaceus). PloS one. 2011; 6: e22957. PMid:21818405 http://dx.doi.org/10.1371/journal.pone.0022957

[48] Nakamura Y, Inloes JB, Katagiri T, Kobayashi T. Chondrocyte-specific microRNA-140 regulates endochondral bone development and targets Dnpep to modulate bone morphogenetic protein signaling. Molecular and cellular biology. 2011; 31: 3019-28. PMid:21576357 http://dx.doi.org/10.1128/MCB.05178-11

[49] Egeblad M, Littlepage LE, Werb Z. The fibroblastic coconspirator in cancer progression. Cold Spring Harbor symposia on quantitative biology. 2005; 70: 383-8. PMid:16869775 http://dx.doi.org/10.1101/sqb.2005.70.007

[50] Greenhough A, Smartt HJ, Moore AE, Roberts HR, Williams AC, Paraskeva C, et al. The COX-2/PGE2 pathway: key roles in the hallmarks of cancer and adaptation to the tumour microenvironment. Carcinogenesis. 2009; 30: 377-86. PMid:19136477 http://dx.doi.org/10.1093/carcin/bgp014

[51] Schramm HM. Extraterritorial osteoclast traits of primary cancer cells. Journal of Solid Tumors. 2011; 1: 65-79.

[52] Bonnelye E, Reboul P, Duval N, Cardelli M, Aubin JE. Estrogen receptor-related receptor alpha regulation by interleukin-1beta in prostaglandin E(2)- and cAMP-dependent pathways in osteoarthritic chondrocytes. Arthritis and rheumatism. 2011; 63: 2374-84. PMid:21506092 http://dx.doi.org/10.1002/art.30398

[53] zhang Y. New Concepts of Germline Gene -reactivated Cancer. . Human Genet Embryol. 2011; 1. http://dx.doi.org/10.4172/2161-0436.1000e101

[54] Zhang Y. Biology of the Mi-2/NuRD Complex in SLAC (Stemness, Longevity/Ageing, and Cancer). Gene regulation and systems biology. 2011; 5: 1-26. PMid:21523247 http://dx.doi.org/10.4137/GRSB.S6510

[55] Moriguchi H MM, Sato C, Chung RT. Generation of Human Induced Pluripotent Stem (iPS) Cells from Liver Progenitor Cells by Two Chemicals and the Clinical Application, Embryonic Stem Cells - Recent Advances in Pluripotent Stem Cell-Based Regenerative Medicine, Craig Atwood (Ed.), ISBN: 978-953-307-198-5, InTech. 2011.

[56] Zhang Y. ETS-FUSions Networking, Triggering and Beyond. Genetics \& Epigenetics. 2010; 3: 1-4. http://dx.doi.org/10.4137/GEG.S4166

[57] Huang S, Ernberg I, Kauffman S. Cancer attractors: a systems view of tumors from a gene network dynamics and developmental perspective. Seminars in cell \& developmental biology. 2009; 20: 869-76.

PMid:19595782 http://dx.doi.org/10.1016/j.semcdb.2009.07.003 
[58] Zhang Y. New Frontiers of Aging Reversal and Aging-Related Diseases Reprogramming. Adv Genet Eng. $2012 ; 1$ : e101. http://dx.doi.org/10.4172/2169-0111.1000e101

[59] Ren X, Wang Y, Wang J, Zhang XS. A unified computational model for revealing and predicting subtle subtypes of cancers. BMC bioinformatics. 2012; 13: 70. PMid:22548981 http://dx.doi.org/10.1186/1471-2105-13-70

[60] Yang S, Wang X, Contino G, Liesa M, Sahin E, Ying H, et al. Pancreatic cancers require autophagy for tumor growth. Genes \& development. 2011; 25: 717-29. PMid:21406549 http://dx.doi.org/10.1101/gad.2016111

[61] Lotz MK, Carames B. Autophagy and cartilage homeostasis mechanisms in joint health, aging and OA. Nature reviews Rheumatology. 2011; 7: 579-87. PMid:21808292

[62] Bai H, Inoue J, Kawano T, Inazawa J. A transcriptional variant of the LC3A gene is involved in autophagy and frequently inactivated in human cancers. Oncogene. 2012; 31: 4397-408. PMid:22249245 http://dx.doi.org/10.1038/onc.2011.613

[63] He C, Bassik MC, Moresi V, Sun K, Wei Y, Zou Z, et al. Exercise-induced BCL2-regulated autophagy is required for muscle glucose homeostasis. Nature. 2012; 481: 511-5. PMid:22258505 http://dx.doi.org/10.1038/nature10758

[64] Metallo CM, Gameiro PA, Bell EL, Mattaini KR, Yang J, Hiller K, et al. Reductive glutamine metabolism by IDH1 mediates lipogenesis under hypoxia. Nature. 2012; 481: 380-4.

[65] Montagner M, Enzo E, Forcato M, Zanconato F, Parenti A, Rampazzo E, et al. SHARP1 suppresses breast cancer metastasis by promoting degradation of hypoxia-inducible factors. Nature. 2012; 487: 380-4. PMid:22801492 http://dx.doi.org/10.1038/nature11207

[66] Diekman BO, Wu CL, Louer CR, Furman BD, Huebner JL, Kraus VB, et al. Intra-articular delivery of purified mesenchymal stem cells from C57BL/6 or MRL/MpJ superhealer mice prevents post-traumatic arthritis. Cell transplantation. 2012. PMid:22889498

[67] Lozy F, Karantza V. Autophagy and cancer cell metabolism. Seminars in cell \& developmental biology. 2012; 23: 395-401. PMid:22281437 http://dx.doi.org/10.1016/j.semcdb.2012.01.005

[68] Baylin SB, Jones PA. A decade of exploring the cancer epigenome - biological and translational implications. Nature reviews Cancer. 2011; 11: 726-34. PMid:21941284 http://dx.doi.org/10.1038/nrc3130

[69] Tsai HC, Li H, Van Neste L, Cai Y, Robert C, Rassool FV, et al. Transient low doses of DNA-demethylating agents exert durable antitumor effects on hematological and epithelial tumor cells. Cancer cell. 2012; 21: 430-46. PMid:22439938 http://dx.doi.org/10.1016/j.ccr.2011.12.029

[70] Koelling S, Miosge N. Stem cell therapy for cartilage regeneration in osteoarthritis. Expert opinion on biological therapy. 2009; 9: 1399-405. PMid:19793003 http://dx.doi.org/10.1517/14712590903246370

[71] Khan IM, Williams R, Archer CW. One flew over the progenitor's nest: migratory cells find a home in osteoarthritic cartilage. Cell stem cell. 2009; 4: 282-4. PMid:19341617 http://dx.doi.org/10.1016/j.stem.2009.03.007

[72] Johnson K, Zhu S, Tremblay MS, Payette JN, Wang J, Bouchez LC, et al. A stem cell-based approach to cartilage repair. Science. 2012; 336: 717-21. PMid:22491093 http://dx.doi.org/10.1126/science.1215157 